\title{
ENVIRONMENTALISM AND THE POLITICS OF EQUITY: EMERGENT TRENDS IN THE BLACK COMMUNITY
}

\author{
Robert Bullard \\ University of Tennessee-Knoxville
}

\section{Beverly Hendrix Wright}

University of New Orleans

Mid-American Review of Sociology, 1987, Vol. XII, No. 2:21-38

The environmental movement in the United Stated emerged with agendas that focused on such areas as wilderness and wildlife preservation, resource conservation, pollution abatement, and population control, and was supported primarily by middle- and upper-middle class whites. Although concern about the environment cuts across racial and class lines, environmental activism has been most pronounced among individuals who have above average education, greater access to economic resources, and a greater sense of personal efficacy (see Morrison, 1973, 1980; Buttel and Flinn, 1978; Bullard, 1983, 1984; Bachrach and Zautra, 1985; Mohai, 1985).

Mainstream environmental organizations were late in broadening their base of support to include blacks and other minorities, the poor, and working-class persons. The "energy crisis" in the seventies was a major impetus which moved many environmentalists to embrace equity issues confronting the poor in this country and countries of the Third World (Morrison, 1980). Environmentalism, over the years, has shifted from a "participatory" to a "power" strategy where the "core of active environmental movement is focused on litigation, political lobbying, and technical evaluation rather than on "más mobilization for protest marches" (Schnaiberg, 1980:366-367).

There is an abundance of evidence which documents that blacks, lower-income groups, and working-class persons are subjected to a disproportionately large amount of pollution and other environmental stressors in their neighborhoods as well as in

* Research for this paper was supported by a grant from the National Science Foundation, grant RII-8413453. Any opinions, findings, conclusions, or recommendations expressed herein are those of the author and do not necessarily reflect the views of the National Science Foundation. 
their workplace (Zwerdling, 1973; Kruvant, 1975; Eckholm, 1977; Berman, 1978; Epstein, 1978, Cutter, 1981; Davis, 1981; Greenberg and Anderson, 1984; Levine, 1982; Kazis and Grossman, 1983; U.S. General Accounting Office, 1983; Epstein et al., 1983; Pollack and Grozuczak, 1984; Bullard, 1983, 1984; Bullard and Wright, 1985, 1986; Collette, 1985; Commission for Racial Justice, 1987). However, these groups have only been marginally involved in the nation's environmental movement.

On the other hand, there is a dearth of studies which document, for example, the way blacks cope with environmental stressors such as municipal solid waste facilities, hazardous waste landfills, toxic waste dumps, chemical emissions from industrial plants, and on-the-job hazards which pose extreme risks to their health. Coping in this case is seen as a response to stress and is defined as "efforts, both action-oriented and intrapsychic, to manage, i.e., master, tolerate, reduce, minimize, environmental and internal demands, conflicts among them, which tax or exceed a person's resources" (Lazarus and Launier, 1978; Lazarus, 1981; Bachrach and Zautra, 1985). Coping strategies employed by individuals who are confronted with a stressor are of two general types: action-focused coping (e.g., individuals and/or group ef forts to directly address the problem), and emotion-focused coping (e.g., efforts to control one's psychological response to the stressor). The decision to take direct action or to tolerate a stressor of ten depends on how individuals perceive thcir ability to do something about or have an impact on the stressful situation (Lazarus, 1981; Collis, et al., 1983; Bachrach and Zautra, 1985).

\section{ENVIRONMENTALISM AND CIVIL RIGHTS}

Blacks were involved in civil rights activities, protests, and demonstrations during the peak period of the environmental movement, roughly during the late sixties and early seventies. Many of the key environmental issues of this period (e.g., wildlife and wilderness preservation, energy and resource conservation, regulation of industrial pollutors) were not high priority items on the civil rights agenda. Social justice, political empowerment, and equal access to education and employment were at the heart of blacks' struggles for parity with the larger society. Blacks were demanding equal access to the workplace. Civil rights advocates and boosters of unrestrained business development were closely aligned on the issue of jobs. In their desperate attempt to improve the economic conditions of their constituents, many black civil rights, business, and political leaders directed their energies toward bringing jobs to their constituents. In many instances, this was achieved at great health risks to black workers and the surrounding communities. The promise of jobs and a broadened tax base in economically depressed communities are of ten seen as acceptable tradeoffs to potential health and environmental risks. This scenario has proven to be the rule in economically depressed and politically oppressed communities in this country (especially in the South) and their counterparts around the world (especially in the Third World).

Workers are of ten forced to make personal sacrifices in terms of job security and job safety. The workplace in this case is an arena where unavoidable trade-offs must be made between jobs and workplace hazards (Nelkins and Brown, 1984). If workers want to keep their jobs, they must work under conditions which may be hazardous to them, their families, and their community. This practice amounts to "environmental blackmail" and is equivalent to economic bondage (Kazis and Grossman, 1983:15-16). Black workers are especially vulnerable to job blackmail because of the threat of unemployment and their concentration in certain occupations.

A large share of the black workforce remains overrepresented in low-paying, low-skill, high risk blue collar and service occupations where there is more than an adequate supply of replacement labor. Black workers are twice as likely to be unemployed as their white counterparts. Fear of unemployment acts as a potent incentive for many blacks to stay in and accept jobs they know are health threatening. The "Gauley Bridges" syndrome (some workers are expendable) persists in the modern day workplace. One of the worst industrial accidents in U.S. history occurred between 1931 and 1932 at Gauley Bridge, West Virginia. More that 5,000 blacks were recruited from the South to construct a tunnel for the Kenawha Power Company, a subsidiary of Union Carbide. Unemployed coal miners in West Virginia understood the dangers of the work conditions under which the tunnel was to be constructed and wanted no part of it. More than 476 workers died and 1,500 were disabled from silicosis. One hundred fifty black workers were hastily buried on the construction site (see Page and O’Brien, 1972; Berman, 1978; Davis, 1981; Agarwal et al., 1985).

There is inherent conflict between the interests of capital and that of labor. Employers are empowered to move jobs (and sometimes hazards) in a political economic world-system (Elling, 1986:19). For example, firms may choose to move their operations from the Northeast and Midwest to the South and Sunbelt, or they may move the jobs to Third World countries where labor is cheaper 
and where there are fewer health and safety regulations. Moreover, labor unions may feel it necessary to tone down their demands for improved work safety conditions in a depressed economy for fear of layoffs, plant closings, and relocation of industries (e.g., moving to right-to-work states which proliferate in the South). The conflicts, fears, and anxieties that are manifested are usually built on the false assumption that environmental regulations are automatically linked to job loss (Brown, 1980).

Economic blackmail also operates at a level which influences financial contributions and business packages between majorityminority business firms. A case in point is the posture that black organizations have taken on the controversial issues of smoking and drinking, and the wholesale ban on cigarette advertizing. Black institutions such as the print and electronic media (e.g., magazines, newspapers, and radio stations), colleges and universities (e.g., their scholarship funds, student newspapers, and sporting events), professional associations, and many mainstream civil rights organizations have been conspicuously silent on the harmful health effects of tobacco and alcohol. For example, the paucity of anti-smoking public service announcements on blackowned and black-oriented radio stations during the "Great American Smokeout" is a classic example of the economic vs environment (health) conflict. The National Bar Association, an organization of black attorneys, in 1986 endorsed a resolution opposing the proposed government wholesale ban on cigarette advertizing. Again, the argument is one of civil rights. That is, the ability of the tobacco giants to exercise their constitutional rights.

Tobacco and liquor companies provide generous contributions to black "causes" and buy considerable advertizing space and time in black newspapers and magazines. Black firms have invested many yeärs of hard work for the advertizing dollars they get from corporate America. The tobacco and liqour industries were among the first major corporations to recognize the utility of the black media in tapping the large black consumer market. Black purchasing power was more than $\$ 200$ billion in 1986. The bulk of black consumer dollars still go to white businesses.

The smoking and drinking message can hardly be missed in the black community because of the proliferation of package stores, bars, and the larger than life stationary billboards which dot the landscape adding to the visual pollution problem. The message comes across loud and clear as it is also affixed to public buses, taxis, and subway trains that circulate within the central city.
Black and lower-income neighborhoods of ten occupy the "wrong side of the tracks," and subsequently receive different treatment when it comes to enforcement of environmental regulations. The sociospatial groupings that emerge in the United States are a result of "the distribution of wealth, patterns of racial and economic discrimination, access to jobs, housing, and a host of other variables" (Lineberry, 1977:11). Housing discrimination and residential segregation artificially restrict millions of blacks to inner-city neighborhoods and areas which pose extreme health risks from pollution and other environmental problems. Political power and economic clout are also key factors which influence the spatial distribution of residential amenities and disamenities and of ten determine "who gets what, where, and how" (Smith, 1974:294).

Many industrial firms, especially waste disposal companies and companies which have a long history of pollution violations, have come to view the black community as a "push-over lacking community organization, environmental consciousness, and with strong and blind pro-business politics" (Collette, 1985:1). Residents of these economically impoverished areas of ten feel powerless in impacting private and governmental pollutors of their neighborhoods (Bullard, 1984). They more of ten end up employing emotion-focused coping by accepting the risks as tradeoffs for jobs. Moreover, the strong pro-jobs stance (a kind of "don't bite the hand that feeds you" sentiment) that permeates the black community aids in the institutionalization of "unacceptable risks" and inequities (Eckholm, 1977; Berman, 1978; Davis, 1981; Bullard, 1984; Elling, 1986).

The 1984 accident at Union Carbide's chemical plant in Bhopal, India is a fairly recent example of an industrial accident that mushroomed into a monumental environmental and health disaster for workers and the surrounding inhabitants. The 1984 accidental leakage of the toxic methyl isocynate gas or MIC killed more than 2,500 individuals and injured some 200,000 persons, making it one of the worse industrial accidents ever recorded (Agarwal et al., 1985). The Bhopal accident spread fear that such a disaster could occur in this country.

Such fears were heightened in communities across the nation. However, residents of Institute, West Virginia, a mostly black town located eight miles west of Charleston have lived in constant fear of exposure to toxic and cancer-causing chemicals from the nearby Union Carbide plant (Begley, 1985; Franklin, 1986). The Institute plant had the distinction of being the only United States producer of the highly toxic methyl isocynate (MIC). 
Local residents for years have come to accept toxic leaks as inevitable and "part of living with the chemical industry" (Page, 1986:3). A major leak which occurred at the Institute plant in the summer of 1985 sent more than 135 local residents to the hospital. The U.S. Environmental Protection Agency's investigation of the Institute plant revealed that more than sixty-two leaks of MIC had occurred between 1980 and 1984 (Agarwal et al., 1985:11; Begley, 1985:24). The Occupational Safety and Health Administration (OSHA) in March, 1986, after a wall-to-wall inspection of the chemical plant, fined Union Carbide $\$ 1.38$ million for 221 "conscious, overt, and willful" safety violations. One of the more serious allegations involved the company using workers as human "canaries" to detect toxic chemical leaks (Page, 1986:8). Institute is a classic example of the environment $v s$ jobs argument which can divide communities. More and more black communities are faced with this dilemma of choosing between economic development and enforcement of environmental and health regulations.

There continues to be considerable overlap between the agendas of economic boosters, black civil rights advocates, and environmentalists. However, the 1980 s have seen the emergence of a small cadre of blacks who advocate environmental issues as civil rights. An alliance has been forged between organized labor, blacks, and environmental groups as exhibited by the 1983 Urban Environment Conference workshops held in New Orleans (Pollack and Grozuczak, 1984). Environmental and civil rights issues were presented as compatible agenda items by this group. Environmental protection and social justice are not necessarily incompatible goals (Miller, 1980; Morrison and Dunlap, 1986).

The recent release of a national study on toxic wastes and race by the Commission on Racial Justice (1987) further highlights environmental concerns as civil rights. The Reverend Ben Chavis, the Commission's Executive Director states:

$[R]$ ace is a major factor related to the presence of hazardous wastes in residential communities throughout the United States. As a national church-based civil rights agency, we believe that time has come for all church and civil rights organizations to take this issue seriously. We realize that involvement in this type of research is a departure from our traditional protest methodology. However, if we are to advance our struggle in the future, it will depend largely on the availability of timely and reliable information (Commission on Racial Justice, 1987:x).
A growing number of grassroots organizations and their leaders have begun to incorporate more action-focused strategies (e.g., protests, neighborhood demonstrations, picketing, political pressure, litigation, etc.) to reduce and eliminate environmental stressors (Bullard, 1983, 1984; U.S. General Accounting Office, 1983; Lash et al., 1984; Pollack and Grozuczak, 1984; Bullard and Wright, 1985, 1986; Commission on Racial Equality, 1987). The national black political leadership has also demonstrated a willingness to take a strong pro-environment stance. The League of Conservation Voters, for example, assigned the Congressional Black Caucus high marks for having one of the best pro-environment voting records (Taylor, 1984:51-52).

Many black communities, however, still do not have the organization, financial resources, or personnel to mount and sustain effective long-term challenges to such unpopular facilities as municipal and hazardous waste landfills, toxic waste dumps, incinerators, and industrial plants which may pose a threat to their health and safety (Bullard and Wright, 1986). This problem is complicated by the fact that blacks of ten must go outside their community to find "experts" on environmental issues. For example, the area of environmental sociology has not been a field which has attracted a large number of blacks. There are less than a half dozen black sociologists who are actively engaged in research in this area. Part of this problem rests with how environmental sociology has been packaged. There is a definite need for core environmental sociology curricula to incorporate distributional impacts.

Black residents are beginning to see payoffs for their work against industrial pollutors. Residents of the tiny all-black town of Triana, Alabama in 1983 won a \$23 million dollar out-of-court settlement against Olin Chemical Company for its contamination of the local people, their water supply, and their favorite catf ish pond which supplied much of this lower-income community's protein.

Residents of the mostly black West Dallas (Texas) neighborhoods have for years lived with the constant bombardment of pollutants from nearby lead smelters (Lash et al., 1984:132-139; Bullard and Wright, 1986:77). Health risks to nearby residents were documented by EPA toxicologists as early as 1981. After years of protests, demonstrations, political pressure, and litigation, an outof-court settlement estimated at nearly $\$ 20$ million was reached in 1985 between the now-defunct RSR Corp., operator of one of the lead smelters, and black residents of a West Dallas neighborhood public housing project whose children suffered irreversible brain damage from exposure to lead pollutants. 


\section{DUMPING ON THE BLACK COMMUNITY}

The correlation between factors associated with disadvantage (i.e., poverty, occupations below management and professional levels, low rent, and high concentration of black residents) and poor environmental quality has been clearly documented (See Buttel and Flinn, 1978; Blum, 1978; Kruvant, 1975; Zwerdling, 1973; Cutter, 1981; Bullard, 1984). Middle- and upper-class residents have been more successful than their lower-income counterparts in using their economic and political clout in changing the course of freeways and the siting of industrial facilities. Subsequently, air and water pollution in central cities can be found at levels up to five times greater than in suburban areas. Institutional barriers, thus, force many central city residents to live and adapt to lower quality physical environments. Various forms of pollution take a heavy toll on central city neighborhoods as a result of the high concentration of industry and power plants, disparate enforcement of pollution laws, heavy vehicle traffic, and congested freeway systems which of ten crisscross lower-income and minority neighborhoods.

The mobility of middle-class persons makes them less vulnerable to environmental problems. People and businesses that can afford to flee to the suburbs do so, while the poor and less advantaged stay behind and suffer from poverty, pollution, and potential health problems. Public policies which tend to favor the affluent over the poor, and disparate enforcement of land use and environmental regulations relegate a large segment of minority residents to less than desirable physical environments, reduce housing and residential options, limit mobility, and increase risks from exposure to potentially health-threatening toxic materials and facilities, where hazardous wastes are disposed.

Finding suitable sites for municipal and hazardous waste disposal facilities has become a critical national problem because people are reluctant to live near a facility where household garbage and toxic substances are dumped. The standard public reaction to waste disposal site selection has been, "Not in My Back Yard," or the "NIMBY" principle. Public of ficials and private industry have in many cases responded using the "PIBBY" principle, "Place in Blacks Back Yard." Waste disposal has become a volatile political issue. The "politics of garbage" has plunged elected of ficials and local residents deep into the problem of where to dispose their municipal waste. What to do with the nation's garbage is not a new problem. However, this problem has been overshadowed by the attention given to the discovery and cleanup of "inactive" toxic waste dumps.

The nation is running out of places to dispose of its waste. More than half the cities in the United States will exhaust their current landfills by 1990. Because of full landfills, many cities are forced to ship their waste to distant sites at high prices. Philadelphia, for example, ships its trash as far away as southern Virginia. The southern states are rapidly becoming the favorite "dumping grounds" for waste generated in the northeast. The problem of what to do with garbage received worldwide attention recently because of the barge carrying 3,100 tons of garbage from Islip, New York floated for weeks and traveled over 6,000 miles in lieu of a state or country that would take the trash.

Siting of landfills in the South has generally followed the path of least resistance. This has of ten meant that poor, black, and powerless communities have had to bear the brunt of the siting practices of municipalities and private disposal companies. Houston, the premier sunbelt city in the seventies and the only major American city which does not have zoning, is a classic example. In Houston, discriminatory public policies, unequal growth within the city, the abscence of effective land use and environmental regulations, and residential segregation contributed to its black neighborhoods becoming the dumping grounds for the city's garbage (Bullard, 1983, 1984). Houston from the twenties through the seventies operated eight garbage incinerators of which six were located in black neighborhoods; one site was located in a Hispanic area and another was located in a mostly white area. The city also operated five sanitary landfills. All five of these landfills were located in black neighborhoods. Moreover, twelve of the thirteen municipal waste disposal sites (incinerators and landfills) were located in Houston's "poverty pockets," the designated Community Development Block Grant (CDBG) program target areas.

Three of the four privately-owned sanitary landfills which operated between 1970 and 1978 and were licensed by the Texas Department of Health to dispose of Houston's municipal waste were also located in mostly black neighborhoods. The waste disposal facility siting practices of city and private waste disposal firms have contributed to black and lower-income communities becoming the "dumping grounds" for household garbage and illegally dumped toxic materials.

Although the waste facility siting pattern of the city and private disposal firms has been known for decades, public opposition in Houston's black community has been modest and 
shortlived. However, beginning in 1979, residents from the mostly black Northwood Manor subdivision located in northeast Houston filed a lwasuit in federal court to stop the construction of a sanitary landfill in their neighborhood. The residents and their attroney charged the Texas Department of Health and Browning Ferris Industries (the "General Motors" of garbage) with oldfashioned racial discrimination in the selection and permitting of the landfill site.

Residents were upset not only because the landfill was near their homes (more than 80 percent of the subdivision residents owned their homes) but was also within 1,400 feet from their high school (which was not equipped with air conditioning), athletic stadium, and their school district's administration building. The North Forest Independent School District is a small suburban district where blacks make up more than 85 percent of the student population; the district is also one of the poorest in the Houston area. Seven North Forest schools form a cluster within a two mile radius of the landfill. Two of the three sanitary landfills which radius of the landrently used to dispose of the city's solid waste are located in this mostly black and impoverished school district.

Although the judge in 1985 ruled against the residents and the landfill was built, black resistance did produce some changes. First, the Houston city council, acting under intense pressure from the black community, passed a resolution in 1980 which prohibited city-owned solid waste trucks from dumping at the controversial landfill. Second, the Texas Department of Health updated its landfill. Second, the use, economic, and socioeconomic data of the area near proposed sanitary landfill sites. Third, black Houstonians sent a clear signal to the state and city government, and private disposal companies that they would fight any future attempts to place garbage dumps, landfills, incinerators, and any other type of waste facility in their area until the burden is equally distributed. The Texas Department of Health between 1979 and 1986 has issued two Type Department of Health between 1979 and 1986 has iand ill permits to dispose of Houston's municipal waste. Both of these sites are located in areas where blacks are in the minority.

Because of illegal dumping of toxic substances at sanitary landfills, black and lower-income neighborhoods are especially at risk since they are burdened with a disproportionately large share of such facilities (See Bullard, 1983, 1984; Bullard and Wright, 1985). The hazardous waste problem continues to be one of the most "serious problem facing the industrial world" (Brownstein, 1982; Epstein et al., 1983:33-39). The nation's Love Canals persist (see Levine, 1982). The U.S. generates over 250 metric tons of hazardous waste each year. EPA's regulations only cover a fraction of this waste, about 40 million metric tons (Office of Technology Assessment, 1983:3). Only about ten percent of this waste is properly disposed of (U.S. Environmental Protection Agency, 1979:12; Epstein et al., 1983:6-11; Fine, 1984). Millions of tons of unregulated hazardous wastes ending up at municipal landfills, designed for household garbage, are released from tank trucks onto back roads, or are dumped directly into sewer systems. The practices of "moonlight dumpers" create health and environmental time bombs that may explode years later (Brown, 1980:267).

Toxic waste facilities are not randomly scattered across the American landscape. Toxic waste facilities are of ten located in communities which have high percentages of poor, elderly, young, and minority residents (Greenberg and Anderson, 1984). An inordinate concentration of uncontrolled toxic waste sites are found in black and Hispanic urban communities (Commission for Racial Justice, 1987:23). On the other hand, large commercial hazardous waste landfills are more likely to be found in rural communities in the "Blackbelt" (U.S. General Accounting Office, 1983:2). The nation's largest commerical hazardous waste landfill is located in Emelle, Alabama (Sumpter County) where blacks comprise 78.9 percent of the population. The nation's fourth largest commerical hazardous waste landfill is located in Scotlandville, Louisiana where blacks make up 93.0 percent of the population. Emelle and Scotlandville account for more than onethird of the estimated landfill capacity in the United States (Commission for Racial Justice, 1987:16). Blacks in these communities are victims of the "triple whammy" of being rural, poor, and politically powerless.

Chemical Waste Management Inc.'s hazardous waste landfill (the "Cadillac" of superdumps) in Emelle contributes more than $\$ 2$ million annually into the economies of Sumpter and Greene Counties, the heart of Alabama's Blackbelt. Pesticides and volatile solvents, however, have begun to show up in the company's own monitoring wells outside the site after less than ten years of operation (Collette, 1985:1). Residents of these economically depressed Blackbelt counties are paying a high health price for the economic benefits derived from the waste disposal firm.

Chemical Waste Management, Inc., which has operated the 2,400 - acre facility under interim status since 1977 , needs four permits: one from the U.S. Environmental Protection Agency (EPA), and three from the Alabama Department of Environmental Management (ADEM). EPA issued a seven year permit for the 
landfill in May, 1987. Alabama has yet to issue its permits to the company. Opposition from local residents has been stepped up in recent years because without a final permit from the state, the company would lose interim status eventually and be forced to close the largest hazardous waste landfill in the nation.

Toxic waste disposal has generated demonstrations in many communities across the country. The first national protest by blacks on the hazardous waste issue came in 1982 after the mostly black Warren County, North Carolina, was selected as the burial site for more than 32,000 cubic yards of soil contaminated with the highly toxic PCBs (polychlorinated biphenyls) which were illegally dumped along the roadways in fourteen North Carolina counties in 1978 (Pollack and Grozuczak, 1984:20). Black civil rights activists, political leaders, and area residents marched and protested against the construction of the PCB landfill in the small town of Afton.

Although the protest demonstrations were unsuccessful in halting the landfill construction, the protests marked the first national attempt by blacks to link environmental issues (hazardous waste and pollution) to the mainstream civil rights agenda. The 1982 demonstrations prompted Congressman Walter E. Fauntroy, who had been active in the protest demonstrations, to initiate the U.S. General Accounting Office (1983) study of hazardous landfill siting in the region. It is not coincidental that the National Association for the Advancement of Colored People (NAACP), the premier civil rights organization, in 1983 passed its first resolution on the hazardous waste issue. The issues raised by the demonstrators were instrumental in getting the Commission for Racial Justice (1987) to sponsor a national study of toxic wastes and race.

\section{CONCLUSION}

Black communities, especially in the South, are just beginning to integrate environmental issues into traditional civil rights agendas. The jobs $v s$ environment argument is now being challenged as black organizations broaden their definitions of civil rights to include air and water quality, hazardous wastes, and other environmental issues. Many black communities, however, still lack the resources to carry on longterm fights with industrial pollutors, public and private waste disposal giants, and moonlight dumpers who target their neighborhoods for their operations. Although the effects of pollutants have no geographic boundaries, black and lower-income residents are of ten trapped in polluted environments because of limited income, institutional barriers in the housing market, politicization of environmental regulations, and discriminatory zoning and land use policies. Institutionalized discrimination, apartheid American style, provides advantages for whites at the expense of people of color.

Institutional racism continues to affect policy decisions related to the enforcement of environmental regulations. Slowly, blacks, lower-income groups, and working class persons are awakening to the dangers of living in a polluted environment. They are beginning to file and win lawsuits challenging government and private industry who would turn their communities into the "dumping grounds" for all types of toxic substances. Whether it is a matter of deciding where a municipal landfill or hazardous waste facility will be located, getting a local chemical plant to develop better emergency notification, or trying to secure federal assistance to clean up an area that has already been contaminated by health-threatening chemicals, blacks and environmental issues if ps must become more involved in environmental issues if they want to live healthier lives.

Finally, black communities need to incorporate environmental safeguards into their agendas for economic development. The promise of jobs may provide short-term solutions to economically depressed black communities. However, health and environmental risks can of ten overshadow the benefits associated with hazardous low-paying occupations. The black community needs to use its institutions (e.g., churches, civic clubs, professional associations, civil rights and political organizations, colleges and universities, develo develop a network of advocates and experts who can develop and articulate long-term economic development and environmental strategies.

\section{REFERENCES}

Agarwal, A., J. Merrifield, and R. Tandon

1985 No Place to Run: Local Realities and Global Issues of the Bhopal Disaster. Knoxville, TN: Highland Center and Society for Participatory Research in Asia.

Bachrach, Kenneth M. and Alex J. Zautra

1985 "Coping with Community Stress: The Threat of a Hazardous Waste Landfill." Journal of Health and Social Begley, Sharon

1985 "Maybe it Could Happen Here." Newsweek 105 (February 4):24. 
Berman, Daniel

1978 Death on the Job: Occupational Health and Safety Struggles in the United States. New York: Monthly Review Press.

Blum, Barbara

1978 Cities: An Environmental Wilderness. Washington, DC: Environmental Protection Agency.

Brown, Michael $\mathrm{H}$.

1980 Laying Waste: The Poisoning of America by Toxic Chemicals. New York: Pantheon Books.

Brownstein, R.

1982 "The Toxic Tragedy." Pp. 1-59 in Nader, Ralph, $\mathbf{R}$. Brownstein, and J. Richards (eds.), Who's Poisoning America: Corporate Pollutors and Their Victims in the Chemical Age. San Francisco: Sierra Club Books.

Bullard, Robert D.

1983 "Solid Waste Sites and the Black Houston Community." Sociological Inquiry 53 (Spring):273-288.

1984 "Endangered Environs: The Price of Unplanned Growth in Boomtown Houston." California Sociologist 7 (Summer):85-101.

Bullard, Robert D. and Beverly H. Wright

1985 "Endangered Environs: Dumping Grounds in a Sunbelt City." Urban Resources 2 (Winter):37-39.

1986 "The Politics of Pollution: Implications for the Black Community." Phylon 47 (March):71-78.

Buttel, Frederick H. and William L. Flinn

1978 "Social Class and Mass Environmental Beliefs: A Reconsideration." Environment and Behavior 10 (September):433-450.

Collette, Will

1985 "Somewhere Else USA: Fighting Back Against Chemical Dumpers." Southern Neighborhoods 9 (September):1-3.

Collis, David L., Andrew Baum, and Jerome E. Singer

1983 "Coping with Chronic Stress at Three Mile Island: Psychological and Biological Evidence." Health Psychology 2:149-66.

Commission for Racial Justice

1987 Toxic Wastes and Race in the United States: A National Report on the Racial and Socio-Economic Characteristics of Communities with Hazardous Waste Sites. New York: United Church of Christ.
Cutter, Susan C.

1981 "Community Concern for Pollution: Social and Environmental Influences." Environment and Behavior 13 (January):105-124.

Davis, Morris E.

1981 "The Impact of Workplace Health and Safety on Black Workers: Assessment and Prognosis." Labor Studies Journal 4 (Spring):29-40.

Eckholm, Erik P.

1977 The Picture of Health: Environmental Sources of Disease. New York: W.W. Norton.

Elling, Ray

1986 The Struggle for Workers' Health: A Study of Six Industrialized Countries. New York: Baywood Publishing Co., Inc.

Epstein, Samuel S.

1978 The Politics of Cancer. San Francisco: Sierra Club Books.

Epstein, Samuel S., Lester O. Brown, and Carl Pope

1983 Hazardous Waste in America. San Francisco: Sierra Club Books.

Fine, John C.

1984 "A Crisis of Contamination." The Sciences (March/April):20-24.

Franklin, Ben A.

1986 "In the Shadow of the Valley." Sierra 717 (May/June):3843.

Greenberg, Michael R. and Richard F. Anderson

1984 Hazardous Waste Sites: The Credibility Gap. New Brunswick: Center for Urban Policy Research.

Kazis, Richard and Richard L. Grossman

1983 Fear at Work: Job Blackmail, Labor and the Environment. New York: The Pilgrim Press.

Kruvant, W.J.

1975 "People, Energy, and Pollution." Pp. 125-167 in Newman, D. and D. Day (eds.), The American Energy Consumer. Cambridge, MA: Ballinger.

Lash, Jonathan, Katherine Gillman, and David Sheridan

1984 A Season of Spoils: The Story of the Reagan Administration's Attack on the Environment. New York: Pantheon Books. 
Lazarus, Richard E.

1981 "The Stress and Coping Paradigm." Pp. 177-214 in Carl Eisdorfer, David Cohen, Alex Kleinman, and Peter Waxman (eds.), Models of Clinical Psychological. New York: Spectrum.

Lazarus, Richard E. and Raymond Launier

1978 "Stress-Related Transactions between Persons and Environment." Pp. 287-327 in Lawrence A. Pervin and Michael Lew is (eds.), Perspectives in International Psychology. New York: Plenum.

\section{Lineberry, Robert L.}

1977 Equality and Urban Policy: The Distribution of Municipal Public Services. Beverly Hills: Sage.

Levine, Adelene G.

1982 Love Canal: Science, Politics, and People. Lexington, MA: Lexington Books.

Miller, A.S.

1980 "Toward an Environmental/Labor Coalition." Environment 22:32-39.

Mohai, Paul

1985 "Public Concern and Elite Involvement in Environmental Conservation." Social Science Quarterly 66 (December):820-838.

Morrison, Denton E.

1973 "The Environmental Movement: Conflict Dynamics." Journal of Voluntary Action Research 2 (Spring):78-85.

1980 "The Soft, Cutting Edge of Environmentalism: Why and How the Appropriate Technology Notion is Changing the Movement." Natural Resources Journal 20 (April):275-298.

Morrison, Denton E. and Riley E. Dunlap

1986 "Environmentalism and Elitism: A Conceptual and Empirical Analysis." "Environmental Management 10:581589.

Nelkins, D. and M.S. Brown

1984 Workers at Risk: Voices from the Workplace. Chicago: University of Chicago Press.

Office of Technology Assessment

1983 Technologies and Management Strategies for Hazardous Waste Control. Washington, DC: Government Printing Office.
Page, Ann L.

1986 "The Union Carbide Institute Accident: The Perception of Risk." Paper presented at the Annual Meeting of the Society for the Study of Social Problems, New York (August).

Page, Joseph and Mary-Win O'Brien

1972 Bitter Wages. New York: Grossman Publishers.

Pollack, Sue and JoAnn Grozuczak

1984 Reagan, Toxics, and Minorities. Washington, DC: Urban Schnaiberg, A. Environment Conference, Inc.

1980 The Environment: From Surplus to Scarcity. New York: Smith, D.M. Oxford University Press.

1974 "Who Gets What When and How: A Welfare Focus for Human Geography." Geography 59 (November):289-297.

Taylor, R.A.

1984 "Do Environmentalists Care about the Poor?" US News and World Report 96:51-52.

U.S. Environmental Protection Agency

1979 "Waste Alert." EPA Journal 5:12.

U.S. General Accounting Office

1983 Siting of Hazardous Waste Land fills and Their Correlation with Racial and Economic Status of Surrounding Communities. Washington, DC: General Accounting Office.

Zwerdling, Daniel

1973 "Poverty and Pollution." The Progressive 37 (January):2529. 